\title{
EFFECTIVENESS OF PLANNED TEACHING PROGRAMME ON KNOWLEDGE REGARDING CERVICAL CANCER AMONG WOMEN
}

\author{
PRAKASH M NAREGAL ${ }^{1 *}$, VAISHALI R MOHITE ${ }^{2}$, ANAGHA V KATTI ${ }^{3}$, PRABHUSWAMI HIREMATH ${ }^{4}$, \\ MAHESH CHENDAKE ${ }^{5}$
}

${ }^{1}$ Department of Child Health Nursing, Krishna Institute of Nursing Sciences, Karad, Maharashtra, India. ${ }^{2}$ Department of Medical Surgical Nursing, Krishna Institute of Nursing Sciences, Karad, Maharashtra, India. ${ }^{3}$ Department of Community Health Nursing, Krishna Institute of Nursing Sciences, Karad, Maharashtra, India. ${ }^{4}$ Department of Mental Health Nursing, Krishna Institute of Nursing Sciences, Karad, Maharashtra, India. ${ }^{5}$ Department of Medical Surgical Nursing, Krishna Institute of Nursing Sciences, Karad, Maharashtra, India. Email: prakash.naregal20@gmail.com

Received: 17 October 2016, Revised and Accepted: 25 October 2016

ABSTRACT

Objectives: To determine the effectiveness of planned teaching programme (PTP) on knowledge regarding cervical cancer among women at selected urban area Karad and to find out the association between knowledge scores with selected sociodemographic variables among women in selected urban areas at Karad.

Methods: Evaluative research approach was used for the study and conducted in urban area Koyana Vasahat, Karad, Maharashtra, India, using one group pre- and post-test design. Systematic proportionate sampling technique was used for selecting 60 women. On the $1^{\text {st }}$ day, structured knowledge questionnaire was used for collecting data, and PTP on knowledge regarding cervical cancer was conducted, followed by posttest on the $7^{\text {th }}$ day. The data collected, tabulated, and analyzed in terms of objectives of the study using descriptive and inferential statistics.

Results: The mean pretest value was 7 and the mean posttest value was 11 with a difference of 4 . The paired $t$-value was 10.2 , ( $p<0.05)$ showing a significant increase in the knowledge regarding cervical cancer and its prevention. There was no significant association between knowledge scores of women with the selected demographic variables.

Conclusion: The study showed that the PTP on cervical cancer was effective in improving the knowledge of women and thus helps them to understand the harmful effects of cervical cancer as well as to take necessary steps for early detection and prevention.

Keywords: Effectiveness, Planned teaching programme, Cervical cancer, Knowledge, Women.

(c) 2017 The Authors. Published by Innovare Academic Sciences Pvt Ltd. This is an open access article under the CC BY license (http://creativecommons. org/licenses/by/4. 0/) DOI: http://dx.doi.org/10.22159/ajpcr.2017.v10i2.15722

\section{INTRODUCTION}

Cancer is a group of diseases characterized by the uncontrolled growth and spread of abnormal cells. If the spread is not controlled, it can result in death [1]. Cervical cancer is one of the leading causes of cancer in women worldwide. One way by which the incidence of this malignant disease can be minimized is by imparting knowledge through health education [2]

Cervical cancer is the fourth most common cancer in women, and the seventh overall, with an estimated 528,000 new cases in 2012. There were an estimated 266,000 deaths from cervical cancer worldwide in 2012, accounting for $7.5 \%$ of all female cancer deaths. Almost nine out of $10(87 \%)$ cervical cancer deaths occur in the less developed regions. Mortality varies 18 -fold between the different regions of the world, with rates ranging from $<2$ per 100,000 in Western Asia, Western Europe, and Australia/New Zealand to more than 20 per 100,000 in Melanesia (20.6), middle (22.2), and Eastern (27.6) Africa [3]

Cervical cancer is the most common gynecological cancer and is the most common cause of death from cancer among women in Thailand, and in almost all patients, the human papillomavirus (HPV) has been found [4].

In India, the incidence of cancer shows that 8 lakh new cases/year, 24 lakh prevalent cases, tobacco-related cancers amenable for primary prevention (48\% in men and $20 \%$ in women), $13 \%$ of cancers in women (uterine cervix) can be screened and prevented [5]
Nearly 500,000 new cases of cervical cancer occur globally annually, $83 \%$ are in the developing world, as are $85 \%$ of the 274,000 deaths associated with cervical cancer [6].

The current Indian population is $1,270,272,105$ (1.27 billion). The incidence of cancer in India is 7090 per 100,000 populations and cancer prevalence is established to be around 2,500,000 (2.5 million) with over 800,000 new cases and 5,50,000 deaths occurring each year. More than $70 \%$ of the cases present in advanced stage accounting for poor survival and high mortality. About $6 \%$ of all deaths in India are due to cancers which contribute to $8 \%$ of global cancer mortality. The annual global incidence of carcinoma cervix is approximately 500,000 cases and India contributes about one-fifth of the burden, i.e., 100,000 cases annually. The impact of cancer in India is far greater than mere number of cancer cases. Its diagnosis causes immense emotional trauma and its treatment a major economic burden [7].

Dutta (2006) revealed contrast to most other cancers, cancer of the cervix affects mainly younger women, with $60 \%$ of cases occurring in women aged 50 or younger. However, cervical cancer can be prevented using a simple test - the cervical smear test. Hence, educating the middle-aged women regarding early detection and prevention of cancer cervix will helps to prevent the mortality and morbidity rate of middle-aged women [8].

A lack of knowledge about HPV and low levels of understanding of HPV vaccination have direct implications for women's participation 
in cervical screening. Despite this, the importance of health education as an integral part of primary prevention for cervical cancer is often ignored [9].

Cervical cancer is a leading cause of morbidity and mortality among women in the low and middle-income countries (LMICs). Of 500,000 new cervical cancer cases diagnosed annually worldwide, 83\% occurred in LMICs where more than $80 \%$ are diagnosed at advanced stage and have poor treatment outcomes. Lack of awareness of risk factors and symptoms for cancer may lead to late diagnosis and poor prognosis [10].

Challenges to cervical cancer screening programs include low public awareness, cost, and access to services. Programs also face shortages of equipment, trained personnel, and clinic and laboratory space, which result in delays in service provision and a general lack of screening coverage on the population level [11].

\section{Problem statement}

"Effectiveness of planned teaching programme (PTP) on knowledge regarding cervical cancer among women at selected urban area at Karad."

\section{Objectives}

1. To assess the pretest knowledge scores regarding cervical cancer among women in selected urban area at Karad.

2. To determine the effectiveness of PTP on knowledge regarding cervical cancer among women at selected urban area at Karad.

3. To find out the association between knowledge scores with selected sociodemographic variables among women in selected urban area at Karad.

\section{Assumption}

The study assumes that women possess some knowledge regarding cervical cancer. PTP will help to increase the knowledge and awareness regarding cervical cancer.

\section{Hypothesis}

H1: The mean post-test knowledge scores of women regarding cervical cancer will be significantly higher than that of their mean pretest knowledge scores 0.05 levels of significance.

H2: There will be a significant association of knowledge scores of women with selected demographic variables.

\section{METHODS}

In view of the nature of the problem selected for the study and objective to be accomplished evaluative research approach was considered. The research design adapted for the study was one group pre- and post-test design. Independent variable of the study was PTP for women regarding cervical cancer, and knowledge scores as measured by structured questionnaires was dependent variable. The study was conducted in urban area at Koyana Vasahat, Karad, Maharashtra, India. Systematic proportionate sampling technique was used for selecting 60 women as a sample of the study. After an extensive review of literature and with the help of experts structured knowledge questionnaire was prepared to assess the level of knowledge of women regarding cervical cancer.

The tools consist of two sections:

Section 1: Demographic variables - age, education, occupation, income, religion, and type of the family.

Section 2: Structured knowledge questionnaire regarding cervical cancer.

\section{Method of data collection}

Ethical approval was obtained from the Institutional Ethics Committee. On the day of pretest, at the very beginning, the women were explained the purpose of the study and informed written consent was obtained from each woman. Pretest was conducted on 17.03.2015 to assess the existing level of knowledge of women regarding cervical cancer followed by PTP on cervical cancer was conducted with the help of lesson plan and A.V. aids (charts and posters). Posttest was conducted on 24.03.2015 by administering the same knowledge questionnaire. Women actively participated and cooperated during data collection.

\section{Plan for data analysis}

The data obtained was analyzed in terms of the objective of the study using descriptive and inferential statistics. The plan of data analysis was developed under the excellent direction of experts in the field nursing and statistics.

The plan of data analysis was as follows:

1. Organization of data in a master sheet.

2. Tabulation of data in terms of frequency, percentage, mean, standard deviation (SD), median, and range to describe the data

3. Classifying knowledge scores using mean and standard deviation (SD) as follows:

$$
\begin{aligned}
& (\mathrm{SD}+\mathrm{X})=\text { Good } \\
& (\mathrm{SD}+\mathrm{X})-(\mathrm{SD}-\mathrm{X})=\text { Average } \\
& (\mathrm{SD}-\mathrm{X})=\text { Poor. }
\end{aligned}
$$

A score of one was awarded to all correct answers while score of zero was awarded to all incorrect answers of structured questionnaire.

4. Inferential statistics were used to draw the following conclusions: Paired t-test was used for testing effectiveness of PTP on knowledge of women, and Chi-square test was used to find association.

\section{RESULTS}

Section A: Distribution of women according to sociodemographic variables.

The data presented in Table 1 shows that maximum numbers of $20(33.3 \%)$ women were in the age group 25-34 years, 33 (55\%) belongs to Hindu religion. The majority of $30(50 \%)$ were studied up to

\begin{tabular}{|c|c|c|c|}
\hline \multirow[t]{2}{*}{ S. No. } & \multirow[t]{2}{*}{ Characteristics } & \multirow[t]{2}{*}{ Category } & \multirow{2}{*}{$\begin{array}{l}\text { Respondents } \\
\text { Frequency (\%) }\end{array}$} \\
\hline & & & \\
\hline \multirow[t]{4}{*}{1} & \multirow[t]{4}{*}{ Age in years } & $25-34$ & $20(33.3)$ \\
\hline & & $35-44$ & $19(31.7)$ \\
\hline & & $45-54$ & $11(18.3)$ \\
\hline & & 55 and above & $10(16.7)$ \\
\hline \multirow[t]{4}{*}{2} & \multirow[t]{4}{*}{ Religion } & Hindu & $33(55)$ \\
\hline & & Christian & $5(8.3)$ \\
\hline & & Muslim & 7 (11.7) \\
\hline & & Others & $15(25)$ \\
\hline \multirow[t]{4}{*}{3} & \multirow[t]{4}{*}{ Education } & $\begin{array}{l}\text { No formal } \\
\text { education }\end{array}$ & 10 (16.7) \\
\hline & & Primary & $15(25)$ \\
\hline & & Secondary & $30(50)$ \\
\hline & & Graduate & $5(8.3)$ \\
\hline \multirow[t]{4}{*}{4} & \multirow[t]{4}{*}{ Occupation } & Skilled worker & $3(5)$ \\
\hline & & Housewife & $42(70)$ \\
\hline & & Business & 7 (11.7) \\
\hline & & Others & $8(13.3)$ \\
\hline \multirow[t]{4}{*}{5} & \multirow[t]{4}{*}{$\begin{array}{l}\text { Monthly income of } \\
\text { the family in rupees }\end{array}$} & Less than 5000 & $03(05)$ \\
\hline & & $5000-10000$ & $11(18.3)$ \\
\hline & & $10001-15000$ & $17(28.3)$ \\
\hline & & More than 15000 & $29(48.3)$ \\
\hline \multirow[t]{2}{*}{6} & \multirow[t]{2}{*}{ Type of the family } & Nuclear & $45(75)$ \\
\hline & & Joint & $15(25)$ \\
\hline
\end{tabular}

Table 1: Distribution of women according to sociodemographic variables $(n=60)$ 
secondary education, $42(70 \%)$ were housewife, 29 (48.3\%) were had monthly family income of more than Rs. 15,000, and 45 (75\%) were from nuclear family.

Section B: Distribution of women according to knowledge scores on cervical cancer.

Table 2 shows that in pretest majority 24 (40\%) woman had good and average knowledge, respectively, and 12 (20\%) had poor knowledge regarding cervical cancer and its prevention. Whereas in post-test majority $30(50 \%)$ woman had good knowledge, 25 (41.6\%) had average knowledge and $05(8.3 \%)$ woman had poor knowledge regarding cervical cancer and its prevention.

Section C: Testing of Hypothesis (H1) for evaluation of the effectiveness of PTP on knowledge regarding cervical cancer.

Table 3 shows that there was a significant increase in posttest scores of women. The mean posttest knowledge score $11 \pm 1$ of women was significantly higher than their pretest knowledge score $7 \pm 2$. The computed t-test statistic value is 10.229 , since the $\mathrm{p}$ value for the test is $<0.05$, hence $\mathrm{H} 1$ is accepted and it shows that the PTP was effective method for improving the knowledge of women regarding cervical cancer.

Section C: Association between pretest knowledge scores on cervical cancer with selected demographic variables of women

Chi-square test was used to find the association of knowledge scores of women with selected demographic variables results showed that there was no significant association between knowledge scores of with selected demographic variables of women.

\section{DISCUSSION}

The study was conducted to assess the effectiveness of a PTP regarding cervical cancer. It was aimed to improve the knowledge of women regarding child abuse and neglect. The mean posttest score $11(\mathrm{SD}=1)$ was higher than the mean pretest score $7(\mathrm{SD}=2)$ these scores indicate that the PTP was effective. The significant difference between the two tests was tested using paired t-test the level of significant was set at the computed $t$-value $(\mathrm{p}<0.001)$ indicated that there was a significant difference in the knowledge of women on cervical cancer.

A similar study conducted to assess the effectiveness of structured teaching programme on knowledge of women regarding cancer cervix. The study was conducted among women in between the age group of 35-55 years selected by purposive sampling technique. Results shows

Table 2: Distribution of frequency and percentage of total knowledge scores of women regarding cervical cancer $(n=60)$

\begin{tabular}{lll}
\hline Knowledge score & \multicolumn{2}{l}{ Frequency (\%) } \\
\cline { 2 - 3 } & Pre-test & Post-test \\
\hline Good (mean+SD) & $24(40)$ & $30(50)$ \\
Average (mean+SD to mean-SD) & $24(40)$ & $25(41.7)$ \\
Poor (mean-SD) & $12(20)$ & $5(8.3)$ \\
\hline
\end{tabular}

SD: Standard deviation

Table 3: Testing of Hypothesis (H1) for evaluation of effectiveness of PTP on knowledge regarding cervical cancer $(n=60)$

\begin{tabular}{ll}
\hline Pre-test $(\mathrm{X} \pm \mathrm{SD})$ & $7 \pm 2$ \\
Post-test $(\mathrm{X} \pm \mathrm{SD})$ & $11 \pm 1$ \\
Paired t-value & $10.229, \mathrm{p}<0.05$ \\
\hline
\end{tabular}

PTP: Planned teaching programme, SD: Standard deviation that among 60 women $48(80.0 \%)$ had a low level of knowledge in pretest and no one had low level of knowledge in posttest. 12 (20.0\%) of women had moderate level of knowledge in pretest and 32 (53.3\%) had moderate level of knowledge in posttest. No one had high level of knowledge in pre-test and $28(46.7 \%)$ had high level of knowledge in posttest. Hence, the structured teaching programme was effective in the sample respondents [8].

A study was conducted was for evaluation of an educational program on cervical cancer for rural women in Mangalore, Southern India. A quasi experimental one group pre- and post-test design was adopted. 30 women were selected using nonprobability convenience sampling technique. Results show that the mean knowledge score of the pretest was $6.83(\mathrm{SD} \pm 2.3)$ and that of the posttest was $14.86(\mathrm{SD} \pm 2.2)$. The $\mathrm{t}$-value computed between the means of the pretest, and the posttest showed that the posttest mean was significantly higher than that of the pretest mean, $t(29)=29.8, p<0.05$. Analysis of the data using Chisquare to find the association between the pretest knowledge score and demographic variables showed that the pretest knowledge score on cervical cancer was independent of all the demographic variables that are age, religion, educational status, occupation, monthly family income, type of family, and source of health information [2].

A similar study was conducted to assess the awareness of cervical cancer among couples; data were collected from two urban slums community in Mumbai. A total of 1958 married women aged from 18 to 49 and their husbands were selected using simple random sampling. Women $(37.7 \%)$ were significantly more aware of cervical cancer than husbands (8.7\%). A slight agreement (kappa statistics=0.16) was observed between husbands and wives on awareness of cervical cancer. Significantly higher percentages of wives were aware of Pap smear test than husbands. Overall, awareness of cervical cancer and Pap smear test among couples is low. There is need to educate and motivate both of them to participate in cervical cancer screening program [12].

\section{CONCLUSION}

Results of the study conclude that women knowledge on cervical cancer was inadequate in pre-test after administration of PTP there was a gain in knowledge, so PTP was effective in increasing the knowledge of women regarding cervical cancer.

\section{REFERENCES}

1. American Cancer Society. Cancer Facts \& Figures 2015. Atlanta: American Cancer Society; 2015.

2. Mary B, D'Sa JL. Evaluation of an educational program on cervical cancer for rural women in Mangalore, Southern India. Asian Pac J Cancer Prev 2014;15(16):6603-8

3. Cervical Cancer Estimated Incidence, Mortality and Prevalence Worldwide; 2012. Available from: http://www.globocan.iarc.fr/old/ FactSheets/cancers/cervix-new.asp

4. Nganwai P, Truadpon P, Inpa C, Sangpetngam B, Mekjarasnapa M, Apirakarn M, et al. Knowledge, attitudes and practices vis-a-vis cervical cancer among registered nurses at the faculty of medicine, Khon Kaen University, Thailand. Asian Pac J Cancer Prev 2008;9(1):15-8.

5. Nair MK, Varghese C, Swaminathan R. Cancer: Current Scenario, Intervention Strategies and Projections for 2015. NCMH Background Papers Burden of Disease in India

6. James OA, Amina OM, Ejike CE, David A, Isah AY. Women in purdah: A study of their knowledge, attitudes and practices in relation to cancer of the cervix. Int Res J Biol Sci 2014;3(7):49-53.

7. Bushan K. Cancer scenario in India. Available from: http://www. dailyexcelsior.com/cancer-scenario-india.

8. Tamizhkodi V, Hemavathy V. Effectiveness of structured teaching programme on knowledge of women regarding cancer cervix. Int J Innov Res Sci Eng Technol 2014;3(11):17090-4.

9. Li J, Kang LN, Li B, Pang Y, Huang R, Qiao YL. Effect of a group educational intervention on rural Chinese women's knowledge and attitudes about human papillomavirus (HPV) and HPV vaccines. BMC Cancer 2015;15:691.

10. Mwaka AD, Orach CG, Were EM, Lyratzopoulos G, Wabinga H, Roland M. Awareness of cervical cancer risk factors and symptoms: 
Cross-sectional community survey in post-conflict Northern Uganda. Health Expect 2016;19(4):854-67.

11. Sudenga SL, Rositch AF, Otieno WA, Smith JS. Brief report: Knowledge, attitudes, practices and perceived risk of cervical cancer among Kenyan women. Int J Gynecol Cancer 2013;23(5):895-9.

12. Donta B, Begum S, Nair S, Naik DD, Mali BN, Bandiwadekar A. Awareness of cervical cancer among couples in a slum area of Mumbai. Asian Pac J Cancer Prev 2012;13(10):4901-3. 